\title{
Improvement of Physical Performance and Quality of Life After Rehabilitation Program for Total Knee Replacement in Geriatric Patient
}

\author{
Andi Dala Intan, Juan Suseno \\ Department of Physical Medicine and Rehabilitation, Sulianti Saroso Infectious Diseases Hospital, Jakarta, \\ Indonesia.
}

\begin{abstract}
Introduction: Early medical rehabilitation after Total Knee Replacement (TKR) was necessary to optimize healing process and reduce pain postoperative that can restrain patients' activity.

Case Presentation: A 66-years-old women had right TKR due to osteoarthritis genu dextra with chronic pain. Patient has muscle weakness on affected leg, and still not able to walk. Medical Rehabilitation (MR) program started one day after surgery for 4 weeks. After 4 weeks of MR program, patient had mild pain, and can walk for $100 \mathrm{~m}$. Pain intensity by visual analogue scale (VAS) reduced from 7/10 to $2 / 10$, knee flexion increased from $70^{\circ}$ to $120^{\circ}$, right quadriceps muscle strength increased from 4 to 5 by manual muscle test (MMT), time to do physical performance by time up and go (TUG) was reduced from 15 to 12.8 sc, activity daily living (ADL) by Barthel Index score increased from 4 to 8 .

Conclusion: Four weeks Rehabilitation Medicine program in geriatric patient with post Right TKR for 4 weeks, effective to improved muscle strength, balance, and ADL.
\end{abstract}

Keywords: Medical rehabilitation, total knee replacement, geriatric, physical performance, quality of life 


\section{ABSTRAK}

Pendahuluan: Terapi rehabilitasi awal setelah prosedur penggantian lutut total, diperlukan untuk mengoptimalisasi proses penyembuhan dan mengurangi nyeri paska operasi yang dapat menghambat aktivitas pasien

Presentasi Kasus: Wanita 66 tahun, paska TKR yang disebabkan oleh osteoarthritis genu dextra dengan nyeri kronis. Pasien memiliki kelemahan pada kaki kanan, dan tidak dapat berjalan. Program rehabilitasi medis dimulai 1 hari paska operasi selama 4 minggu. Setelah program rehabilitasi 4 minggu, nyeri pasien berkurang, dan dapat berjalan sejauh $100 \mathrm{~m}$. Skala nyeri diukur dengan visual analogue scale (VAS) menurun dari $7 / 10 \mathrm{ke} 2 / 10$, fleksi lutut meningkat dari $70^{\circ}$ menjadi $120^{\circ}$, kekuatan otot quadriceps kanan meningkat dari 4 ke 5 dengan manual muscle test (MMT), waktu yang diperlukan untuk melakukan aktivitas fisik dengan time up and go (TUG) berkurang dari 15 menjadi 12.8 detik, aktivitas sehari-hari yang diukur dengan Barthel Index Score, meningkat dari 4 menjadi 8.

Kesimpulan: Program rehabilitasi selama 4 minggu pada lansia dengan riwayat TKR kanan selama 4 minggu, didapatkan efektif untuk meningkatkan kekuatan otot, keseimbangan, dan ADL

Kata kunci: Rehabilitasi medik, total knee replacement, lansia, performa fisik, kualitas hidup

Correspondent Detail:

\section{Andi Dala Intan}

Email: dalabatara82@gmail.com

Department of Physical Medicine and Rehabilitation, Sulianti Saroso Infectious Diseases Hospital, Jakarta, Indonesia.

\section{INTRODUCTION}

Management of Osteoarthritis (OA) of hip/knee comprises non-pharmacologic, pharmacologic and surgery, according to several clinical guidelines recommend combining treatment options prior to the consideration of surgical interventions. Symptomatic knee osteoarthritis is a chronic disease affecting about 9.3 million adults aged $\geq 45$ years old in the USA. The study has proven the surgery in severe OA was effective. ${ }^{1}$ Total Joint Replacement must be done for OA Grade 3-4, especially accompany by restriction of activity. ${ }^{1,2}$ The frequency of surgery rates in hip/knee OA were 16\%-23\% in primary care by cohorts, and 18\%-50\% in referred hospital. The frequency of joint replacement increases annually, due to the increasing of the OA prevalence. ${ }^{3}$

Wound healing and restore the function were essential on medical rehabilitation process. The program should design gradually, repetitive, regularly each day and individually, have proven can reduce the hospital length of stay for $70 \%$ of patients. The beneficial program should be done immediately and for 12 weeks after surgery. ${ }^{1-4}$

The serial of medical rehabilitation program in TKR is important to optimized healing 
processes. ${ }^{5,6,7,8}$ Preoperative rehabilitation program may have benefit in reduce postoperative pain and increase activity, although there has no different in hospital length of stay and quality of life. The patient has motivated to keep active as tolerated and exercise after discharged from hospital. Pain can be an important factor to restriction of activity. The intractable pain in post-operative period can lead to be chronic pain. The frequent of structures damaged in TKR surgery that cause postoperative pain were skin, joint lining, soft tissue around the joint, and bone, beside uncertain of neuropathic pain. ${ }^{4,5}$

Assessment before and after Rehabilitation Program were physical performance, consists of pain by VAS, quadriceps muscle strength by MMT, walking distance, ROM, TUG, risk of fall, and percentage of weight bearing (WB); activity daily living by Barthel index, and quality of life by EQ5D. Functional assessment according to International Classification of Functioning Disability and Health (ICF) can be used in post-operative conditions. ${ }^{1,6}$

\section{CASE REPORT}

A geriatric woman aged 66 years old had chief complaint as pain on the right knee one day after TKR surgery. She couldn't walk and had weakness on her right leg. Her past diagnosis was bilateral knee OA Grade 3. She already got painkiller and activity restriction.

She visited the Medical Rehabilitation Department, as a referral patient from Orthopaedic surgeon, one day after TKR surgery. There has no history of pre surgery rehabilitation management. Before the surgery, she had permanent chronic pain since 6 month ago, with VAS at scale of 4-6 out of 10, accompanied by referred pain to the posterior and right thigh. She couldn't climb the stairs, walking over than $300 \mathrm{~m}$ because of pain. She had problem in overweight since 20 years ago.

Patient had history of type II Diabetes since 7 years ago, controlled by the anti-diabetic medicine, and had Hypertension, controlled by amlodipine and valsartan. The physical performance has showed the independent level of ADL as housewife. She has involved in many community activities. Her cognitive state was normal according the age. She was inpatient since 3 days before surgery, until 5 days after surgery.

From physical examination we found vital sign was stable. The assessment on one day after surgery was in immobilize condition, no dyspnea, pain on the right leg (VAS 7/10) while movement, edema on affected knee, right quadriceps MMT was 4, knee ROM flexion was $70^{\circ}$. Barthel Index score was 4 (Total dependent ADL), Risk of Falls by Morse was 35 (mild risk of falls). The assessment on day 3 , there were improvement on VAS become 4, Barthel index score was 10 , the risk of fall by Morse was 40 (mild risk of falls). After discharge from hospital, patient has a program as a home exercise program similar by hospital exercise. The results from assessment on two weeks after discharge were VAS was 4-5/10, there was tightness on right gastrocnemius, pain on right hip and knee while movement, ROM of knee flexion was $90^{\circ}$, the MMT of right knee extensor was 4 , the TUG was 15 
second, the score of Barthel index was 16, and the risk of falls was 50 (mild risk of falls). The assessment on four weeks after surgery have found the VAS was 3, the tight on right gastrocnemius was improved, ROM of the knee flexion was $120^{\circ}$, MMT of the extensor knee was 5, the TUG was 12.8 second, Barthel index was 18 , and the risk of falls was 50 (mild risk of falls).

From Thorax X-Ray examination, it found she had Cardiomegaly with aorta elongation, and normal electrocardiography; Laboratory result for random blood glucose was $162 \mathrm{mg} / \mathrm{dl}$ with medication.

Evaluation of the ICF has found there were limitation of the body Functions (b280), Sensation of pain (b429), Functions of the cardiovascular system, other specified and unspecified (b455), Exercise tolerance functions (b710), Mobility of joint functions (b715), Stability of joint functions (b720), Mobility of bone functions (b730),
Muscle power functions (b735), Muscle tone functions (b740), Muscle endurance functions (b780), Body structures (s410), Activities and Participation (d450), Walking (d455), Moving around (d465), Moving around using equipment (d489), Moving around using transportation (d598), Selfcare (d649), Household tasks (d649). The ICF evaluation on this patient has showed the problems on body function and body structures in musculoskeletal system, cardiovascular system functions, activities and participation.

The goals on short-term management were reducing pain and active mobilization. Furthermore, the long-term goals were motivating patient to build long-term commitment for active mobilization and back to daily activity, by maintain proper body mechanic and joint protection, healthy lifestyle, and increasing cardiorespiratory endurance. the goal of discharge planning as follows.

Table 1. Exercise Prescriptions

\begin{tabular}{lll}
\hline \multicolumn{1}{c}{ Timeline } & \multicolumn{1}{c}{ Activities } & \multicolumn{1}{c}{ Exercise Prescription } \\
\hline $\begin{array}{l}\text { Post op day 1 after } \\
\text { surgery }\end{array}$ & $\begin{array}{l}\text { Bed mobility active start to } \\
\text { out of bed (passive) }\end{array}$ & $\begin{array}{l}\text { Flexion knee, strengthening (passive tolerated) } \\
\text { breathing \& chest expantion and sitting balance } \\
\text { exercise. Once/day }\end{array}$ \\
Post op day 2 & Out of bed mobility active & $\begin{array}{l}\text { Flexion knee, strengthening (active assisted } \\
\text { tolerated). Once/day }\end{array}$ \\
Post op day 3 to & Start walking with aid & $\begin{array}{l}\text { Achieve at least 70-90 degrees of flexion. Gait } \\
\text { training with walker 3 m, Partial weight bearing } \\
\text { discharge }\end{array}$ \\
& & (PWB) 10-20\% from Body Weight. Once/day \\
\hline
\end{tabular}


The Patient has received pharmacologic management. i.e., $1,5 \mathrm{mg}$ vicilin 3 times a day for 3 days, routine $4 \mathrm{mg}$ Glimepiride once a day, $500 \mathrm{mg}$ Metformin 3 times a day, $8 \mathrm{mg}$ Candesartan once a day, $10 \mathrm{mg}$ Amlodipine once a day, Lansoprazole 2 times a day, $500 \mathrm{mg}$ Paracetamol three times a day. Patient has special diet for diabetes and hypertention.

Rehabilitation medicine program described as follow; $1^{\text {st }}$ day after surgery, patient has exercise prescription for early mobilization; the $2^{\text {nd }}$ day patient has gradually exercise, bed mobility, gradually reclining until proper sitting, chest expansion, flexion knee, strengthening as tolerated, dynamic sitting balance, sitting to transfer; the $3^{\text {rd }}$ day after surgery, patient has started out of bed, and mobility by sitting on a chair, stimulated on standing balance and walking with walker around the bed for $3 \mathrm{~m}$, along 20 minutes/session. For home exercise we give gradually mobilization same as before, physical activities about 2-3 Mets and independent ADL.

During the rehabilitation process, patients have high adherence to undergo rehabilitation session 3 times per week, each 2 session, we given regular education before / after training and when evaluating session every 2 weeks, education is emphasized to achieve functional targets.

Two weeks after discharge in outpatient clinic we give exercise endurance, strengthening \& ROM exercise for Quadriceps-HamstringsGastrocnemius-Gluteus medius muscles, ambulation training progressive partial weight bearing gradually from $20 \%$ body weight.

The evaluation on the $4^{\text {th }}$ weeks, there were improvement on ROM of knee flexion was $120^{\circ}$, and able to walk for $100 \mathrm{~m}$. Pain intensity by VAS reduced to 2-3, increasing of ADL, TUG test was 12.8 second, Barthel index score reduced to 4-18 (mild dependent, cannot climbing stairs). She still has mild risk of falls and suggested to use ambulation aids. Activities have improved from 2 Mets to 3-4 Mets.

Patient has physical therapy by Transcutaneous Electrical Nerve Stimulation (TENS) and Ultrasound Diathermy (US) 40 minutes each session, 3 times/weeks.

In addition to the exercise training provided, we give regular verbal education. During the rehabilitation process the patient is given routine education 2 times at inpatient, 2 times per week while in outpatient clinic until weeks $4^{\text {th }}$. 


\section{RESULTS}

Table 2. Rehabilitation Program's Result in Patient with Total Knee Replacement (TKR)

\begin{tabular}{lcccc}
\hline \multicolumn{1}{c}{ VARIABLES } & $\begin{array}{c}\mathbf{1}^{\text {st }} \text { day } \\
\text { after TKR } \\
\text { (inpatient) }\end{array}$ & $\begin{array}{c}\mathbf{3}^{\text {rd }} \text { day } \\
\text { after TKR } \\
\text { (inpatient) }\end{array}$ & $\begin{array}{c}\mathbf{2} \text { weeks } \\
\text { after TKR } \\
\text { (outpatient) }\end{array}$ & $\begin{array}{c}4^{\text {th }} \text { weeks } \\
\text { after TKR } \\
\text { (outpatient) }\end{array}$ \\
\hline VAS & 7 & $4-5$ & 4 & $2-3$ \\
ROM (Knee Flexion) & $0^{\circ}$ & $70^{\circ}$ & $90^{\circ}$ & $120^{\circ}$ \\
MMT (Right Quadriceps) & 4 & - & 4 & 5 \\
Walking Distance (meters) & - & $3 \mathrm{~m}$ & $50 \mathrm{~m}$ & $100 \mathrm{~m}$ \\
PWB (\%) & - & $10-20 \%$ & $50 \%$ & $75 \%$ \\
TUG (second) & - & - & $15 \mathrm{~s}$ & $12.8 \mathrm{~s}$ \\
ADL Barthel Index & 4 & 10 & 16 & 18 \\
Risk Of Falls (Morse) & 35 & 40 & 50 & 50 \\
QOL (EQ5D) & 55 & - & - & 80 \\
\hline
\end{tabular}

There were increasing score of MMT on right quadriceps, walking distance TUG, Barthel index, risk of falls, Quality of Life, and physical activity (mets) have shown in table 1 . Evaluation ICF after 4 weeks was there were improving on body Functions (b280), Sensation of pain (b429), Functions of the cardiovascular system, other specified and unspecified (b455), Exercise tolerance functions (b710), Mobility of joint functions (b715), Stability of joint functions (b720),Mobility of bone functions (b730), Muscle power functions (b735), Muscle tone functions (b740), Muscle endurance functions (b780), Body structures (s410), Activities and Participation (d450), Walking (d455), Moving around (d465), Moving around using equipment (d489), Moving around using transportation (d598), and Self-care (d649). There was no improvement in Household tasks (d649).

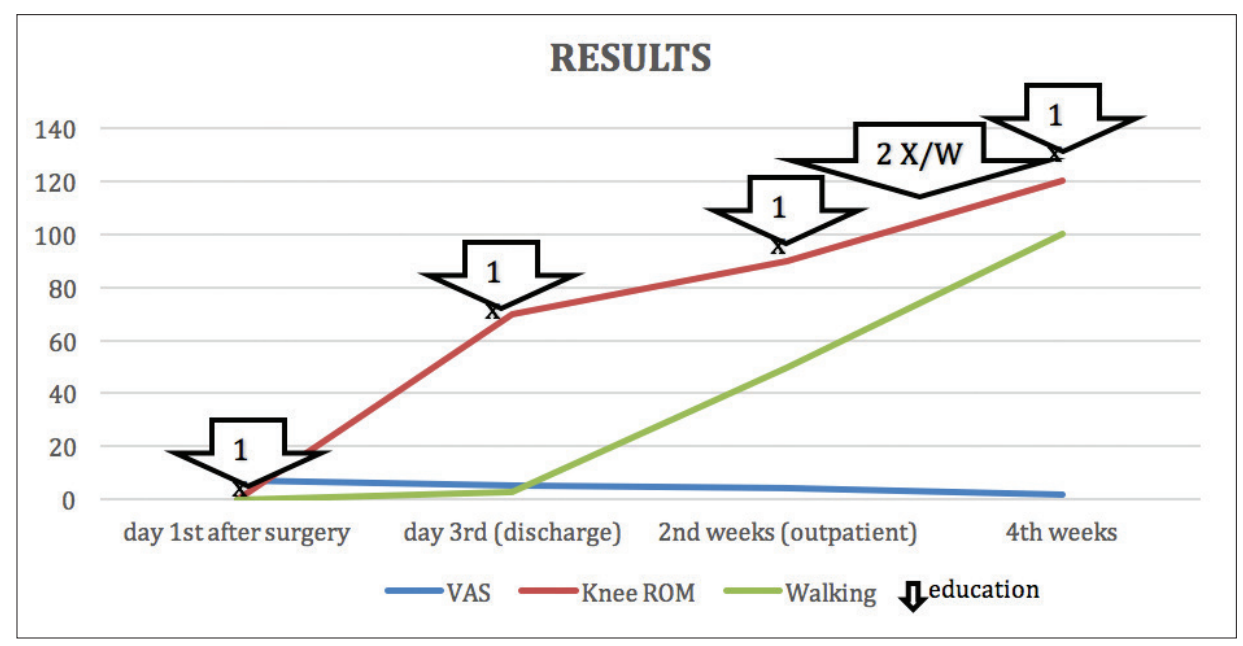

Graphic 1.

Rehabilitation

Program's Result in

Patient with Total

Knee Replacement

(TKR) 


\section{DISCUSSION}

Rehabilitation diagnosis in accordance to ICF shows that patient's disability is dominant affected body functions and structures in musculoskeletal systems and activities \& participation in mobility functions \& community life, there is no significant in environment factors and personal factors. However, her ability to perform general tasks and demands is affected mildly. In more detail, she had the following health problems, immobilization, mild dependency of ADL. Only a few ICF-based problems and personal factors that can hinder the rehabilitation process are not shown, so the ability to optimize the patient's functional duration can be shorter to achieve. According to the improvement from the ICF perspective, it occurs due to changes in the structure and function of mobility and joint activity after progressive rehabilitation.

Patient had a risk of fall, and should concern and manage the diabetes, hypertention, and overweight by being active and controlled the diet.

During hospitalization, patient's short-term management goals included reducing pain, increasing ROM gradually and preventing immobilization. She was then able to overcome his acceptance on current conditions and hospital environment, including her compliance to immobilize. Reducing pain and mobilization progression, she performed physical therapy once per day at hospital and 2-3 times per day at home after discharge.

Patient has moved from the bed to sit on the chair and walking in the room with walker assisted for 5-10 minutes under supervision.
She needs to achieve 3 Mets of physical activities and independent ADL at home. Patient has to continue the exercise programs routinely and encouraging the family to conduct a healthy lifestyle and increasing muscles endurance for 3 times a week.

A week post-hospital discharge, patient was able to walking inside her home. Two weeks post-discharge, she could walk outdoor assisted by walker, and 4 weeks after surgery she could 100 meters walking with walker with mild knee pain. She also able to walked outside home and has normal range of motion (ROM) without experiencing severe symptoms. The pattern and walking process must be restored correctly, by stimulation proprioceptive on affected limb. Patient has trained to step by consideration and making the normal pattern of gait by feeling the transfer of the body weight to affected limb gradually. Pressure and support applied to the joint replacement side are gradually in stages starting from $20 \%$ of body weight and subjective tolerance of patient complaints. ${ }^{10,11}$

Home-based Exercise program should be integrated in a long comprehensive care of musculoskeletal \& degenerative problems patients and into the existing healthcare systems at the modest cost. The programs should be accompanied by highly trained health professionals and more detailing to list the problems with active participation of patients themselves and by her families.

Patient is then suggested for home-based Exercise program, such as walking 3 times a day for 30 minutes maximum; if possible, increase the distance per walking. She has to do stretching (tolerated) before and after exercise; 
beware of any symptoms while walking and remember to stop if symptom(s) occur or do breathing exercise regularly when exercise and after or when symptom(s) was appear; adequate nutrition and sleep; and body weight reduction.

From several researched, early mobilization post TKR surgery can result in a reduced LOS only in $<5$ days. Trials that reported these positive results showed that early mobilization can be achieved within 24 hours of operation. This positive gain was achieved without an increase in negative outcomes. Effectiveness after knee replacement to improve the functional abilities are $12^{\text {th }}$ weeks exercise intervention..$^{10}$ In this case report, the rehabilitation program has done for 4 weeks, and has improvement in physical performance (quadriceps muscle strength, walking distance, TUG, Barthel Index) and quality of life.

The rehabilitation management after surgery until $4^{\text {th }}$ weeks is needed as early as possible, to speed up the recovery phase and restore the patient's function in her ADL as a housewife. With an appropriate rehabilitation regiment, strong collaboration of rehabilitation teams, close multidisciplinary collaboration, high patient motivation, and adherence to rehabilitation, the achievement of targets for patients given therapy can be faster, and improving of quality of life. ${ }^{11}$

\section{CONCLUSION}

Rehabilitation medicine management in geriatric patient with post Right Total Knee Replacement for 4 weeks, improved physical performance, activity daily living and quality of life.

\section{REFERENCES}

1. Braddom RL. Physical Medicine and Rehabilitation. 5th rev. ed. Missouri, USA: Elsevier Health Sciences, 2015. p.709-38

2. Barten J, Smink A, Swinkels IC, Veenhof C, Schers HJ, Vlieland TV et.al,. Factors Associated With Referral to Secondary Care in Patients With Osteoarthritis of the Hip or Knee After Implementation of a Stepped-Care Strategy. Journal of Arthritis Care \& Research. American College of Rheumatology. 2017(69):21625

3. Guerra ML, Singh PJ, Taylor NF. Early mobilization of patients who have had a hip or knee joint replacement reduces length of stay in hospital : a systematic review. Journal of Clinical Rehabilitation. 2015 Sep;29(9):844-54.

4. Greengard S, Carey E. Recovery Timeline for TKR : Rehabilitation Stages and Physical Therapy. Healthline. 2019.

5. Tayrose G, Newman D, Slover J, Jaffe F, Hunter T, Bosco J. Rapid Mobilization decreases length of stay in joint replacement patients Journal of Bull Hosp Jt Dis. 2013;71(3):222-6.

6. World Health Organization. International classification of functioning, disability and health : ICF. WHO Library Cataloguing-in-Publication Data. 2018. p.45-171

7. Jonsson, H., Olafsdottir, S., et al. Incidence and prevalence of total joint replacements due to osteoarthritis in the 
elderly: risk factors and factors associated with late life prevalence in the AGESReykjavik Study. BMC musculoskeletal disorders. 2016;17(1), 14.

8. Losina, Elena, et al. Lifetime medical costs of knee osteoarthritis management in the United States: impact of extending indications for total knee arthroplasty. Arthritis care \& research. 2015;67.2: 203-215.

9. Ramlall, Y., Andrion, J. J. D., Cameron, H. U., \& Sawhney, M. Examining pain before and after primary total knee replacement (TKR): A retrospective chart review. International. Journal of Orthopaedic and Trauma Nursing. 2019.
10. O’Brien, J., Hamilton, K., et al. Improving physical activity, pain and function in patients waiting for hip and knee arthroplasty by combining targeted exercise training with behaviour change counselling: study protocol for a randomised controlled trial. Trials Journal Biomedcentral. 2018;19(1), 425.

11. Wang, L., Lee, M., Zhang, Z., Moodie, J., Cheng, D., \& Martin, J. Does preoperative rehabilitation for patients planning to undergo joint replacement surgery improve outcomes? A systematic review and meta-analysis of randomised controlled trials. BMJ. 2016; 6(2), e009857. 